\title{
Structural anti-quality characteristics of range and pasture plants
}

\author{
EMILIO A. LACA, LISA A. SHIPLEY, AND EDWARD D. REID
}

Authors are assistant professor, Department of Agronomy and Range Science, University of California, Davis, assistant professor, Department of Natural Resource Sciences, Washington State University, Pullman, Wash., and research assistant, Department of Range Ecology and Management, University of Idaho, Moscow, Ida.

\begin{abstract}
Structural anti-quality characteristics are physical plant traits that reduce the performance and productivity of herbivores and quality of their agricultural products. Most structural anti-quality characteristics of plants affect the rate at which herbivores gather and ingest forages, reducing the total amount of food obtained or increasing the time necessary to obtain food. Structural anti-quality can substantially influence searching time (e.g., plant crypticity, distribution), cropping time (e.g., plant fibrousness, tensile and shear strength ), and bite size (e.g., plant canopy structure, spinescence). Plant structural characteristics can also reduce digestion (e.g., silica), cause injury (e.g., spines, awns, burrs, calluses), or reduce the quality of animal products, such as wool (e.g., propagules). The effects of structural antiquality characteristics depend on the morphology of the herbivore, especially its size, the morphology of the focal plant, and their context within the habitat. Integrated grazing management plans should consider options to reduce the negative effects of structural anti-quality. Carefully selecting appropriate livestock species with previous experience, and the appropriate season of grazing can minimize anti-quality on rangelands. Because structural anti-quality may actually promote sustainability of grazing systems by preventing severe defoliation, or by providing refuges for highly desirable forages, it may not be desirable to completely counteract their effects.
\end{abstract}

Key Words: bite size, chewing, canopy structure, intake rate, physical plant defenses, spines

The performance and production of wild and domestic herbivores depends on receiving adequate quality and quantity of forage over many time scales. Biochemical and physical characteristics of plants that reduce the performance of herbivores feeding on them compared to a similar plant without the trait are defined as 'anti-quality'. Structural anti-quality characteristics include all physical plant traits that cause grazing avoidance that do not directly depend on the chemical composition of plant tissues (Briske 1996). Plants may have individual structural anti-quality

We would like to thank K. Launchbaugh for suggestions on the manuscript. This work is partially based on research supported by grant IS-2331-93C from USIsrael Binational Fund for Agricultural Research and Development, and award 970133 from NRI Competitive Grants Program/USDA to E. Laca.

Manuscript accepted 25 Nov. 00.

\section{Resumen}

Las características estructurales anti-calidad son características físicas que reducen el comportamiento productivo de los herbívoros y la calidad de sus productos agropecuarios. La mayoría de las características estructurales anti-calidad afectan la tasa a la cual los herbívoros recolectan e ingieren el forraje, reduciendo la cantidad de alimento obtenido o incrementando el tiempo necesario para obtener el alimento. Las características estructurales anti-calidad pueden influir substancialmente el tiempo de búsqueda (por ejemplo, plantas encriptadas y su distribución), tiempo de cosecha (por ejemplo, la fibrocidad de la planta, y la resistencia tensil y de corte) y el tamaño de la mordida (por ejemplo, estructura de la copa de la planta, cantidad de espinas). Las características estructurales de la planta también pueden reducir la digestión (por ejemplo, sílice), causar daño (por ejemplo, espinas, aristas, callos, pelos) o reducir la calidad de los productos animal, tales como la lana (por ejemplo propágulos). Los efectos de las características estructurales anti-calidad dependen de la morfología del herbívoro, especialmente su tamaño, la morfología de la planta focal y su contexto dentro del hábitat. Los planes de manejo integral del apacentamiento deben considerar opciones para reducir los efectos negativos de las características estructurales anti-calidad. Seleccionando cuidadosamente la especie animal apropiada, basados en experiencias previas, y la estación de apacentamiento apropiada se puede minimizar la anti-calidad en los pastizales. Debido a que las características estructurales anti-calidad puede promover la sustentabilidad de los sistemas de apacentamiento al evitar la defoliación severa o preveer refugios para las plantas forrajeras altamente deseables, puede ser no del todo deseable contraatacar sus efectos

traits such as canopy architecture, growth form, and mechanical deterrents to grazing, as well as spatial and temporal characteristics of groups of plants that potentially reduce the value of a plant as food. Here we review the modes of action and effects on herbivores of different structural anti-quality characteristics of plants, including crypticity and spatial distribution, canopy structure, plant fibrousness and resistance to chewing, tensile and shearing strength, stems and pseudostems, spinescence, awns, burrs, and calluses, and silica. In addition, we offer suggestions for management techniques that will reduce the negative affects of structural characteristics in herbaceous and woody range and pasture plants that will yield improved animal productivity and wool or hide quality. 


\section{Modes of Action and Effects of Structural Anti-quality Characteristics of Plants}

\section{Overview} herbaceous and woody range plants primarily serve to reduce the rate at which herbivores can gather and ingest (harvest) forages (Fig. 1). Herbivores invest up to half of their day harvesting food (Bunnell and Gillingham 1985, Belovsky and Slade 1986, Owen-Smith 1988). Therefore, structural characteristics of plants that increase the time needed to find, crop, and/or chew food of sufficient quality and quantity reduce the time available for other life requisites (e.g., parental care, thermoregulation, rumination, and rest) and thus reduce production and survival. Therefore, forage intake has the potential to limit herbivore production in most rangeland and pasture ecosystems. In fact, the effects of structural anti-quality may exceed that of the more well-known biochemical anti-quality characteristics of plants (Shipley et al. 1999, Van der wal et al. 2000). Structural plant characteristics such as spines, burrs, calluses, and awns can also injure animals, affecting their survival (Cooper and Owen-Smith 1986, Crampton 1974), reduce the quality of products such as hides and wool (Stubbendieck et al. 1992), or reduce digestibility of forage (e.g., silica, Van Soest 1982, Fig. 1). Many aspects of plant structure have multiple negative effects on the ingestion-digestion process and animal performance. Therefore, for each structural plant characteristic, it is important to understand its main mode of action, level of experimental support for its anti-quality
Structural anti-quality traits of both

properties, field context in which the trait is most detrimental to animals, body size of most susceptible herbivores, and characteristics of the target plant (Table 1). For example, short plants are more detrimental to large animals when forage availability is low and grazing time is limited (Table 1). Short plants may be used more efficiently by small ruminants with low requirements than by larger animals (females vs. males, sheep vs. cattle, Illius and Gordon 1987, 1991). This knowledge can be used by scientists and managers to foresee and reduce the negative effects of each of the following plant anti-quality characteristics.

\section{Crypticity and spatial distribution}

Cryptic plants are difficult to find and thus reduce foraging efficiency of herbivores (Feeny 1976). Apparent plants allow animals to walk directly from one preferred plant to the next, whereas a cryptic plant requires that foragers search blindly until plants are randomly encountered. Foraging efficiency and intake rate are affected by the time it takes herbivores to find desirable forages. In any given rangeland, intake rate declines and energy expenditure for locomotion increases as animals become more selective in their food choices (Murray 1991, Laca and Demment 1996). These effects are more pronounced when desirable plants are cryptic.

Quantitative experimental information about the effects of crypticity and spatial distribution of forages on herbivore nutrition is scarce. Models and experiments in controlled conditions clearly indicate that intake rate increases when desirable forages are easy to detect and encounter. Animals learn to associate forages with visual cues forage more efficiently than

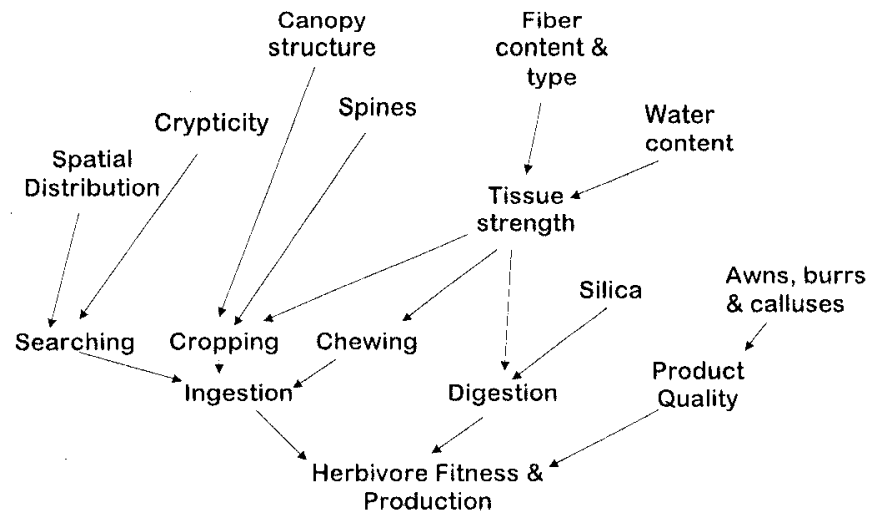

Fig. 1. The modes of action by which structural antiquality characteristics of plants influence animal fitness and production. without cues (Bazely and Ensor 1989, Edwards et al. 1997, Howery et al. 1999a,1999b, Kidunda and Rittenhouse 1992, Ortega and Laca 1997, Renken et al. 1998). A simple model of grazing behavior showed that when herbivores can detect desirable plants or patches from a distance, harvesting is greater than when plants are cryptic (Demment and Laca 1993). Crypticity reduces an animal's harvesting rate the most when bites are small and little forage is available. Model predictions were qualitatively corroborated in experiments with cattle in artificial foraging arenas where food patches were marked using flags or other visual cues (Laca and Ortega 1996). Cattle exhibited greater foraging efficiency (intake/distance walked) when feed pellets were marked with flags, a visual cue immediately recognized by cattle. Likewise, Howery et al. (1999a) found that steers searching for fixed or variable forage locations in a 0.64 ha arena with artificial visual cues spent more time feeding and less time in non-foraging activities than without cues. Animals exposed to fixed and variable forage arrangements with cues also located feed more efficiently and had higher intakes than without cues.

Like crypticity, certain spatial distributions of forage plants may serve as an antiquality trait by affecting herbivore preference and efficiency (Vivås and Sæther 1987, Danell et al. 1991). When a preferred food is distributed randomly or uniformly, herbivores have lower intake rates than when distributions are patchy (Laca and Ortega 1996). Cattle had a higher intake rate on feed pellets with flags than those without flags only when spatial distribution was uniform or random, but not when feed was patchy (Laca and Ortega 1996). The fact that intake rate in patchy distributions is less affected by crypticity indicates that cattle use mechanisms other than visual cues to detect patches of desirable forage. Cattle and sheep can overcome the effects of crypticity when food locations are predictable based on spatial memory (Edwards et al. 1997, Laca 1998). However, spatial memory is expected to be effective only in selecting feeding sites or larger areas (Bailey et al. 1996).

Whether plant dispersion and patchiness serves an anti-quality function depends on the spatial scale considered. Foraging intensity per shrub, tree, small patch, or feeding station increases with decreasing patch density (Vivås and Sæther 1987, Danell et al. 1991, Shipley and Spalinger 1995). More specifically, herbivores take larger bites and more bites per stem in 
Table 1. Structural antiquality characteristics of plants, including their effects on animal performance, the level of experimental proof

\begin{tabular}{|c|c|c|c|c|c|}
\hline Anti-quality trait & Effects & Proof & Context & Animal & Plant \\
\hline$\overline{\text { Crypticity }}$ & Lower bite and intake rate & Limited & Low herbage mass & Large & Rare \\
\hline Random distribution & Lower bite and intake rate & Limited & Low herbage mass & Large & Low density \\
\hline Short stature & Reduced bite mass and intake & Plenty & Low herbage mass & Large & Low bulk density \\
\hline Low bulk density & Reduced bite mass and intake rate & Some & Low herbage mass & Large & Short \\
\hline Pseudostems & Reduced bite mass and intake rate & Some & Low herbage mass & Large and small & Short \\
\hline Stems, (hedging, wolf plant) & $\begin{array}{l}\text { Reduced bite mass, bite rate and } \\
\text { intake rate; barrier; injury }\end{array}$ & Good & $\begin{array}{l}\text { Early stages of } \\
\text { bunchgrass }\end{array}$ & Medium & $\begin{array}{l}\text { Bunchgrass, } \\
\text { Shrub }\end{array}$ \\
\hline Tensile and shearing strength & $\begin{array}{l}\text { Reduced bite area, bite mass and } \\
\text { bite rate, fatigue }\end{array}$ & Limited & $\begin{array}{l}\text { Late phenological stages; } \\
\text { tropical grasses }\end{array}$ & Small & Grass \\
\hline $\begin{array}{l}\text { Fibrousness, resistance to } \\
\text { chewing }\end{array}$ & $\begin{array}{l}\text { Reduced bite and intake rate; } \\
\text { lower passage rate }\end{array}$ & Plenty & $\begin{array}{l}\text { High herbage mass; } \\
\text { tropical pastures }\end{array}$ & All & $\begin{array}{l}\mathrm{C} 4 \text {, mature or } \\
\text { dormant plants }\end{array}$ \\
\hline Twig thickness & $\begin{array}{l}\text { Restricted relation between bite mass } \\
\text { and quality; reduced bite rate }\end{array}$ & Good & & Small, Medium & Dormant shrubs \\
\hline Spinescence & $\begin{array}{l}\text { Reduced bite mass and rate; injury; } \\
\text { disease; }\end{array}$ & Plenty & Low primary productivity & Medium & Woody plants \\
\hline Awns, calluses, burs & $\begin{array}{l}\text { Reduce bite and intake rate injury; } \\
\text { disease; damage product }\end{array}$ & Good & & $\begin{array}{l}\text { All, particularly } \\
\text { sheep, goats }\end{array}$ & $\begin{array}{l}\text { Mature; Stipa, } \\
\text { Bromus, Hordeum }\end{array}$ \\
\hline Silica & $\begin{array}{l}\text { Injury; promotes tooth wear; } \\
\text { urinary calculi }\end{array}$ & Good & High primary productivity & Grazers & Grass \\
\hline
\end{tabular}

patches that contain fewer stems and are scattered further apart, presumably to maximize intake rate at the expense of forage quality. The proportion of a small patch (i.e., feeding station) removed by a herbivore increases with decreasing density. Therefore animals may have a higher harvesting rate at the patch when patches are further apart. However, this trend is reversed at the scale of a large patch or habitat (i.e., large groups of shrubs/trees). More animals spend more time in habitats that provide more food, and thus relatively more biomass is removed and daily intake is increased in more productive habitat patches (Vivås and Sæther 1987, Danell et al. 1991, Edenius 1991).

\section{Canopy structure}

Canopy structure determines the size and arrangement of bites of vegetation in space. Bite mass is one of the main determinants of short-term intake rate by herbivores (Black and Kenney 1984, Spalinger and Hobbs 1992, Gross et al. 1993). The mechanisms of cropping (i.e., severing or prehending a bite) and chewing are such that, for a wide range of bite mass, intake rate increases up to 10 fold with increasing bite mass (Gross et al. 1993, Shipley et al. 1994). This range certainly brackets bite mass values that normally can be obtained by livestock and wildlife in rangelands and most pastures. Thus, under most rangeland conditions, herbivores are at least partially limited by bite mass they can obtain.
In grasslands, bite mass is often constrained by the structure, especially height and bulk density, of the canopy of grasses and forbs (Black and Kenney 1984). In an experiment using controlled canopy structures, bite mass of cattle was $0.26 \mathrm{~g}$ in 8 $\mathrm{cm}$ tall swards, but only $0.12 \mathrm{~g}$ in $4-\mathrm{cm}$ swards, despite a constant forage mass kept at $500 \mathrm{~kg} / \mathrm{ha}$ by varying bulk density (Ungar et al. 1991). Moreover, livestock seem to select patches that yield greater intake rate (Arnold 1987, Laca et al. 1993). Thus, sward structure has a pronounced effect on selective defoliation patterns of vegetation. Herbaceous plants that yield small bites tend to be avoided, and plants that offer large bites of good quality forage tend to be preferred. Depending on the relative and absolute abundance of tall and short plants in the grassland, short plants may become unprofitable to the herbivore (Laca et al. 1994a).

Similarly, browsing herbivores tend to prefer woody plant species and portions of plants that provide larger leaves and thicker and longer annual growth twigs (Danell et al. 1994, Shipley et al. 1998). The arrangement of leaves and stems on some plants, such as willow (Salix spp.), allow herbivores to strip many leaves in 1 bite, which substantially increases intake (Stapley 1998). Larger herbivores can obtain a larger bite when branching architecture allows them to take multiple stems in one bite (Vivås et al. 1991). However, small, thin stems branching at wide angles may serve to deter herbivory by separating bites (Myers and Bazely 1991, Vivås et al. 1991). In some plant species, herbivory increases branching and produces a hedge effect that reduces bite size and accessibility. However, in other plant species such as birch (Betula spp), moose browsing increased length, diameter and leaf size of re-grown stems, which were in turn used more heavily than unbrowsed trees (Danell et al. 1985).

Canopy structure and its effect on intake rate changes with plant phenology and plant fibrousness. Because nutritional quality is often inversely related to bite mass, bite mass is a trade-off between harvesting rate and nutritional quality (Shipley et al. 1999, Vivås et al. 1991). For example, as grasses mature from vegetative to reproductive stages, overall nutritional value declines (Van Soest 1982, Nelson and Moser 1994). During the vegetative stage of grass phenology, the nutritional quality differs little among plant parts. As grasses mature, the proportion of more fibrous stems and older leaves increases, resulting in large variation in nutritional quality within a plant or sward (Hacker and Minson 1981). To compensate for the decline in quality as grasses mature, herbivores select higher quality parts. However, increased selectivity reduces harvesting rates by slowing cropping rate and reducing bite size to the point that adjacent plants that allow higher intake become preferred. How well herbivores can compensate for changes in nutritional quality depends upon the animal's 
size and mouth morphology. Because of large mouth parts, larger herbivores are generally less able to select small, more nutritious parts of plants than smaller herbivores. Likewise in woody range plants, the amount of lignin and cell wall generally increases with twig diameter (Vivås and Sæther 1987), but intake rate also increases. Because large herbivores require a greater intake rate than do smaller herbivores to meet their nutritional requirements, plants with smaller leaves and twigs are less profitable and provide a greater defense against large herbivores (Spalinger and Hobbs 1992).

\section{Plant fibrousness and resistance to chewing}

Resistance to ingestive chewing, measured as the number of chews per unit mass of particles comminuted to pass a $1.18 \mathrm{~mm}$ sieve, is positively related to fiber content (McLeod et al. 1990, Balch 1971). Therefore, intake rate can decline with increasing fiber content in forages because of the associated increase in chewing time necessary to adequately process the forage. In herbaceous plants, resistance to ingestive chewing can be considerably greater for stems than for leaves (McLeod et al. 1990). Stems also are more resistant than leaves to chewing during rumination. Chewing during ingestion accounts for much of the variation in intake rate within feeding stations, and thus fibrousness directly reduces intake rate (Laca et al. 1994b). For example, short-term intake rate of moose (Alces alces), deer (Odocoileus virginianus), and snowshoe hares (Lepus americanus) was lower on red maple stems (Acer rubrum, $64 \%$ neutral detergent fiber, NDF) than on red maple leaves (32\% NDF) for a wide range of bite sizes (Shipley and Spalinger 1992). Likewise, intake rate of cattle was greater for the less fibrous legume-leaf fractions than for grass leaf and stem fractions (McLeod and Smith 1989). Sheep eating perennial ryegrass (Lolium perenne L.) with high shear strength had a significantly lower intake rate $(6.5 \mathrm{~g} / \mathrm{min})$ than did those eating ryegrass with low leaf shear strength $(7.6 \mathrm{~g} / \mathrm{min}$; MacKinnon et al. 1988). Although ryegrass progenies that differed in shearing strength by $50 \%$ differed in harvesting rate, there was no discernible difference in their digestion rate or potential degradability. Thus, effects of fibrousness on eating rate are beyond the effects of fiber on forage digestibility and retention time.

\section{Tensile and shearing strength}

Increasing tensile strength of foliage tends to reduce bite size by reducing the bite area that may be cropped (Demment et al. 1992). Bite area declined more steeply with increasing bulk density in dallisgrass (Paspalum dilatatum Poir.) than in wild oats (Avena fatua L.). This difference was attributed to the greater tensile strength of dallisgrass, with leaf blades $14 \%$ lighter (4.3 vs. $4.9 \mathrm{mg}$ ) and $89 \%$ stronger (11.5 vs. 6.1 Newtons/blade) than wild oats (Demment et al. 1992). At equal bulk density, dallisgrass foliage was expected to be 2.2 times stronger than oat foliage. Although tensile strength is not an absolute limitation to biting (Hughes et al. 1991), it may reduce intake rate by imposing a cost in terms of effort, energy, and time. When grazing swards of high tensile strength, steers sometimes failed to sever the bites of grass apprehended, and had to release some of the forage before being able to complete the biting motion (E. A. Laca, University of California, Davis, personal observation).

Bite mass on woody plants is also controlled by the force required to sever forage. Obtaining a larger bite usually requires that the animal "prune" a thicker twig or multiple twigs (Vivås et al. 1991). Because the force required to crop a twig increases curvilinearly with twig diameter (Shipley et al. 1999), thick or multiple twigs may restrict bite mass or at least slow cropping rate, particularly for small browsing herbivores. As twig diameter increases, herbivores must switch from using incisors to molars to crop bites, which slows intake (Cooper and OwenSmith 1986).

\section{Stems and pseudostems}

Cured reproductive stems can effectively deter grazing by cattle, particularly when plants are in an early phenological stage (Ganskopp 1993, Ganskopp et al. 1992). Plants with stems were less likely to be grazed and severely defoliated than those without stems. In experiments with hand-constructed swards, Flores et al., (1993) found that a bottom layer of dallisgrass stems acted as a barrier to grazing, but pseudostems had no detrimental effect. The effects of the layer of stems were evident only if the stems were higher than the biting depth animals would select in a similar sward made only of leaf laminae.

\section{Spinescence}

Herbivores generally have lower intake rates on plants with spines, thorns, prickles, and hairs than the same plants with these structures removed (Cooper and Owen-Smith 1986, Dunham 1980, Gowda 1996). When intake rate is reduced, herbi- vores spend more time foraging, but often not enough to compensate completely (Cooper and Owen-Smith 1986). Spines influence harvesting rate by reducing bite mass and/or decreasing cropping rate (Belovsky et al. 1991).

Spines reduce bite mass by impeding stripping motions and separating leaves, which forces animals to crop leaves individually (Milewski et al. 1991, Pellew 1984, Stapley 1998). Large herbivores that require large bites, such as kudus (Tragelaphus strepsiceros)and giraffes (Giraffa camelopardalis), may be particularly affected by spinescence. Thorns and spines also reduce the fraction of a twig that may be pruned and the diameter at which the twig is clipped (Cooper and Owen-Smith 1986). Therefore, small leaves combined with thorns have the greatest anti-quality effects on medium to large herbivores (Belovsky et al. 1991, Gowda 1996, Milewski et al. 1991) because their bite size is more severely restricted.

Spines also slow cropping rate by requiring herbivores to carefully manipulate plants in their mouths to avoid pain and injury (Belovsky et al. 1991, Cooper and Owen-Smith 1986, Dunham 1980). Hooked thorns especially catch on lips, tongues, and ears (Cooper and OwenSmith 1986). The influence of thorns on ingestion depends on the size of the foraging animal. Smaller animals can maneuver mouthparts more easily among thorns to pluck small leaves, and therefore, thorns may be less effective in reducing cropping rates. Pointed muzzles and mobile lips on larger animals may be adaptations for feeding on thorny vegetation (Myers and Bazely 1991). However, large animals with larger mouths, like giraffes and rhinos (Diceros bicornis), often can bite off and chew thorns that impede smaller animals (Owen-Smith 1988, Pellew 1984). In fact, spines may also reduce harvesting rates of very small herbivores, such as plains woodrats (Neotoma micropus), by physically impeding or injuring them as they climb up to harvest berries, seeds, and foliage (Cooper and Ginnett 1998).

Spinescence also can injure and physically block animals from feeding on the plant or cause so much pain that the animal refuses to feed on it. For example, prickles on species such as blackberry (Rubus idaeus) can interlock, holding stems together and making the patch difficult or impossible to penetrate (Myers and Bazely 1991). Some injuries from spines cause chronic, rather than immediate pain and injury. Scratches and scar tissue can 
be found in the digestive tract of kudus and domestic goats inhabiting Acacia spp. woodlands, suggesting that thorns may injure and scar buccal or esophageal mucosa, and may make these animals more susceptible to disease (Cooper and Owen-Smith 1986).

Because spinescence slows harvesting rate of herbivores, the anti-quality effects of spines varies with habitat productivity, accessibility, proportion of the landscape covered, nutrient concentration and seasonal dynamics in relation to its neighbors (Grubb 1992). The consequences of reduced intake rate to a herbivore are more pronounced where intake rate is more limiting, such as in arid environments that have a low primary productivity, where, not surprisingly, spines are more common (Belovsky and Schmitz 1991).

\section{Awns, burrs and calluses}

Many plant species have evolved mechanisms of propagule dispersal that are detrimental to herbivores. Awns, calluses and spikelets such as in Avena, Stipa, Bromus, Sitanion and Hordeum spp., are noxious to livestock because they are bristly or scabrous, bearing stiff hairs arranged like harpoons, or sharp calluses. These structures can bury into soft tissues (eyes, mouth, nostrils, and ears), causing distress and infections (Crampton 1974). Sheep and other fiber-producing livestock are also susceptible to injury in any area of the skin, because their hide is more delicate than that of bovines (American Sheep Industry Association 1996). Such lesions cause distress, reduce productivity, contaminate the carcass, and reduce the quality of the hides. Fruiting structures with thorns and hooks, such as those produced by burr clover (Medicago polymorpha L.), as well as propagules from several grasses, contaminate and reduce the value of the fleece (American Sheep Industry Association 1996, Stubbendieck et al. 1992).

\section{Silica}

Several studies have examined how silica affects herbivores, most notably its effect on digestion (Van Soest 1982), tooth wear (Riet-Correa et al. 1986), and as a cause of urinary calculi (Emerick 1987, 1988). Silica is an indigestible structural component of most grasses (Van Soest and Jones 1968). Silica in grasses reduced in vitro digestibility 3 units per unit of silica (Van Soest and Jones 1968). Furthermore, silica may affect intake rates in a similar fashion as other structural compounds. Grasses with higher silica general- ly have more rigid and sharper edges that can affect harvesting rates by reducing relative bite mass (Reid 2000). For example, sheep presented with similar sized plants of indiangrass (Sorghastrum nutans (L.) Nash) and big bluestem (Andropogon gerardii Vitman) strongly prefer big bluestem despite no noticeable differences in nutritional quality between the grasses. Indiangrass, which has higher silica content than big bluestem, has stiffer and sharper-edged blades, which limited bite mass (Reid 2000). Small herbivores, such as voles (Microtus ochrogaster), also prefer grasses with lower silica content (GaliMuhtasib et al. 1992). However, the effects of silica on preference do not seem to be universal. Shewmaker et al. (1989) found no relationship between silicon content and forage preference in sheep.

High silica content of plant tissues can also be detrimental to herbivores by promoting rapid tooth wear (Baker et al. 1959, Riet-Correa et al. 1986). The productive life span of cattle, particularly reproductive beef and dairy cows, can extend beyond 7-8 years. Yet, where forages have high silica content, and when animals are chronically forced to graze close to the soil in excessively short swards, tooth wear may cause culling of otherwise productive animals because they cannot bite and chew enough forage to realize their production potential. Silicon content in forages may further reduce animal health by causing urolithiasis (Baker et al. 1961a,1961b, Bailey 1976).

\section{Conclusions and Management Implications}

Any plant trait that affects herbivore diet choice serves an anti-quality function (Belovsky and Schmitz 1991). Therefore, the efficacy of any structural anti-quality characteristic of plants depends on the characteristics of other plants in the environment, the nutritional status of the herbivore, and herbivore species. Because of the relationship between body size and a variety of morphological and physiological characteristics of ruminants (Demment and Van Soest 1985, Illius and Gordon 1987, Shipley et al. 1994), body size has an overriding influence on the effects of any particular anti-quality trait (Table 1).

A number of anti-quality traits affect herbivores by making it hard for them to bite, handle, and chew forages. However, the ability of herbivores to deal with different canopy structures, stems, and spines improves with experience and learning
(Flores et al. 1989a, 1989b, Ortega-Reyes and Provenza 1993a, 1993b). Therefore, grazing experience can be used by managers to reduce the effects of structural anti-quality of plants on herbivores.

This review of structural anti-quality factors leads to the following conclusions:

1. Structural anti-quality can have multiple modes of action, from reducing shortterm intake rate by increasing search and locomotion costs, to lowering passage rate by increasing resistance to chewing, to directly injuring herbivores.

2. Reduction of intake rate by limitation of bite mass and bite rate is widespread. These limitations are more severe for large herbivores with high physiological demand in environments with low primary productivity.

3. Effects of anti-quality factors depend on herbivore characteristics, notably body size, characteristics of the focal plant, and its context within the habitat. The influence of a given anti-quality trait depends on the characteristics of other plants available to the herbivore. Thus, because quality, diversity and quantity of potential forages vary with season and successional stage, so does the effects of a particular anti-quality factor.

4. Structural and chemical anti-quality factors are interdependent. Forage fibrousness, spines, and stems are structural barriers based on lignin and cellulose, which are quantitative chemical defenses.

As a direct consequence of the fact that structural anti-quality factors tend to limit forage intake over the long term by constraining ingestion constraints, management recommendations follow general grazing management guidelines to ensure that herbivores achieve sufficient quality and quantity of intake. The following management recommendations should be considered in the context of a general grazing management plan developed for the enterprise as a whole.

1. Carefully select livestock species and type to match the forage characteristics of specific zones and paddocks.

2. Ensure pastures have forage that optimizes grazing efficiency for specific herbivores. For example, small ruminants are better suited for grasses with shorter swards.

3. Periodically "clean" grasslands to remove old stems and standing dead forage by grazing with very high animal densities for short times or by mowing. When using animals as the cleaning tool, use animals with low physiological demands and good teeth, like horses, wethers and mature dry cows. 
4. Determine the abundance of plants with high silica in different paddocks and assess their impact on tooth wear. Those paddocks should be used by livestock with good teeth whose longevity in the herd is not an issue.

5. Determine which paddocks and seasons have an abundance of plants with awns, calluses, burs and other structures that cause injuries and reduce the quality of fiber, hides, and carcasses. Plan grazing management such that susceptible livestock are not in these paddocks when noxious plant structures are abundant.

6. In areas with challenging forage structure, use animals that have experience with the forages, or gradually introduce livestock to the new forages. This is best accomplished by placing naïve animals with experienced ones at times when their productivity and survival does not depend on structurally defended forages.

These management guidelines are proposed to prepare herbivores for the structural challenges presented by forage plants. It is, however, important to acknowledge positive aspects of anti-quality factors on grazed ecosystems. By preventing complete defoliation, or by providing refuges for highly desirable forages, structural anti-quality traits may promote the sustainability of the system. Thus, these management guidelines must be considered as potential components of integrated grazing management plans that incorporate effects on animal productivity and plant communities.

\section{Literature}

American Sheep Industry Association. 1996. SID sheep production handbook. American Sheep Industry Association. Production, Educ. and Res. Counc., Englewood, Colo.

Arnold, G.W. 1987. Influence of the biomass, botanical composition and sward height of annual pastures on foraging behaviour by sheep. J. Appl. Ecol. 24:759-772.

Bailey, C.B. 1976. Effects of ammonium chloride on formation of siliceous urinary calculi in calves. Can. J. Anim. Sci. 56:359-360.

Bailey, D.W., J.E. Gross, E.A. Laca, L.R. Rittenhouse, M.B. Coughenour, D.M. Swift, and P.L. Sims. 1996. Mechanisms that result in large herbivore grazing distribution patterns. J. Range Manage. 49:386-400.

Balch, C. C. 1971. Proposal to use time spent chewing as an index of the extent to which diets for ruminants possess the physical property of fibrousness characteristic of roughages. Brit. J. Nutr. 26:383-392.

Baker, G., L. H. P. Jones, and A. A. Milne. 1961a. Opal uroliths from a ram. Aust. J. Agr. Res. 12:473-482.
Baker, G., L. H. P. Jones, and I. D. Wardrop. 1959. Cause of wear in sheep's teeth. Nature 184:1583-1584.

Baker, G., L. H. P. Jones, and I. D. Wardrop. 1961b. Opal phytoliths and mineral particles in the rumen of the sheep. Aust. J. Agric. Res. 12:473-482.

Bazely, D. R. and C. V. Ensor. 1989. Discrimination learning in sheep with cues varying in brightness and hue. Appl. Anim. Beh. Sci. 23:293-299.

Belovsky, G. E. and O. J. Schmitz. 1991. Mammalian herbivore optimal foraging and the role of plant defenses, pp. 1-28. In: R. T. Palo and C. T. Robbins (eds.), Plant defenses against mammalian herbivory. CRC Press Inc., Boca Raton, Fla.

Belovsky, G. E. and J. B. Slade. 1986. Time budgets of grassland herbivores: body size similarities. Oecologia 70:53-62.

Belovsky, G. E., O. J. Schmitz, J. B. Slade, and T. J. Dawson. 1991. Effects of spines and thorns on Australian arid zone herbivores of different body masses. Oecologia 88:521-528

Black, J. L. and P. A. Kenney. 1984. Factors affecting diet selection by sheep: II. Height and density of pasture. Aust. J. Agr.. Res. 35:551-563

Briske, D. D. 1996. Strategies of Plant Survival in Grazed Systems: a Functional Interpretation, pp. 37-67. In: J. G. Hodgson and A. W. Illius (eds.), The ecology and management of grazing. CAB International, Wallingford, Oxon, UK.

Bunnell, F. and M. P. Gillingham. 1985. Foraging behavior: dynamics of dining out, pp 53-79. In: R. White and R. Hudson (eds), Bioenergetics of wild herbivores. CRC Press, Boca Raton, Fla.

Cooper, S. M. and T. F. Ginnett. 1998. Spines protect plants against browsing by small climbing mammals. Oecologia 113:219-221.

Cooper, S. M. and N. Owen-Smith. 1986. Effects of plant spinescence on large mammalian herbivores. Oecologia 68:446-455.

Crampton, B. 1974. Grasses in California. University of California Press, Berkeley, Calif.

Danell, K., R. Bergstrom, and L. Edenius. 1994. Effect of large mammalian browsers on architecture, biomass, and nutrients of woody plants. J. Mammal. 75:833-844.

Danell, K., L. Edenius, and P. Lundberg. 1991. Herbivory and tree stand composition: Moose patch use in winter. Eco. 72:1350-1357.

Danell, K., K. Huss-Danell, and R. Bergstrom. 1985. Interactions between browsing moose (Alces alces) and two species of birch in Sweden. Ecol. 66:1867-1878.

Demment, M. W. and E. A. Laca. 1993. The grazing ruminant: models and experimental techniques to relate sward structure and intake, pp. 439-460. Proceedings VII World Conference on Animal Production, Invited Papers, Canadian Soc. of Anim. Sci., Edmonton, Edmonton, Can.
Demment, M. W., and P. J. Van Soest. 1985. A nutritional explanation for body-size patterns of ruminant and nonruminant herbivores. Am. Nat. 125:641-672.

Demment, M. W., E. A. Laca, N. G. Seligman, and E. D. Ungar. 1992. Integrating sward structure and ingestive behavior to determine intake rate in cattle. Univ. of California Volcani Center, Davis, Calif.

Dunham, K. M. 1980. The feeding behaviour of a tame impala Aepyros melampus. Afr. J. Ecol. 18:253-257.

Edenius, L. 1991. The effect of resource depletion on the feeding behaviour of a browser: winter foraging by moose on Scots pine. J. Appl. Ecol. 28:318-328.

Edwards, G. R., J. A. Newman, A. J. Parsons, and J. R. Krebs. 1997. Use of cues by grazing animals to locate food patches: An example with sheep. Appl. Anim. Beh. Sci. 51:59-68.

Emerick, R. J. 1987. Answer to silica stones. South Dakota Farm Home Res. 38:10-12.

Emerick, R. J. 1988. Urinary calculi, pp. 523-531. In: D. C. Church (ed.), The ruminant animal. Digestive physiology and nutrition. Prentice Hall, Englewood Cliffs, N. J.

Feeny, P. 1976. Plant apparency and chemical defense. Rec. Adv. Phytochem. 10:1-40.

Flores, E. R., F. D. Provenza, and D. F. Balph. 1989a. The effect of experience on the foraging skill of lambs: Importance of plant form. Appl. Anim. Beh. Sci. 23:285-291.

Flores, E. R., F. D. Provenza, and D. F. Balph. 1989b. Role of experience in the development of foraging skills of lambs browsing the shrub serviceberry. Appl. Anim. Beh. Sci. 23:271-278.

Flores, E. R., E. A. Laca, T. C. Griggs, and M. W. Demment. 1993. Sward height and vertical morphological differentiation determine cattle bite dimensions. Agron. J. 85:527-532.

Gali-Muhtasib, H. U., C. C. Smith, and J. J. Higgins. 1992. The effect of silica in grasses on the feeding behavior of the prairie vole, Microtus ochrogaster. Ecol. 73:1724-1729.

Ganskopp, D. 1993. Effect of low densities of senescent stems in crested wheatgrass on plant selection and utilization by beef cattle. Appl. Anim. Beh. Sci. 38:227-233.

Ganskopp, D., R. Angell, and J. Rose. 1992. Response of cattle to cured reproductive stems in a caespitose grass. J. Range Manage. 45:401-404.

Gowda, J. H. 1996. Spines of Acacia tortilis: What do they defend and how? Oikos 77:279-284.

Gross, J. E., L. A. Shipley, N. T. Hobbs, D. E. Spalinger, and B. A. Wunder. 1993. Functional response of herbivores in foodconcentrated patches: Tests of a mechanistic model. Ecol. 74:778-791.

Grubb, P. J. 1992. A positive distrust in simplicity- lessons from plant defences and from competition among plants and among animals. J. Ecol. 80:585-610. 
Hacker, J. B. and D. J. Minson. 1981. The digestibility of plant parts. Herbage Abs. 51:459-482.

Howery, L. D., D. W. Bailey, and E. A. Laca. 1999a. Impact of spatial memory on habitat use. Pages 91-100 in Grazing behavior of livestock and wildife, p. 91-100. In: K. L. Launchbaugh, J. C. Mosley, and K. D. Sanders (eds.) Idaho For., Wildl. and Range Exp. Sta. Bull. 70 .

Howery, L. D., D. W. Bailey, G. B. Ruyle, and W. J. Renken. 1999b. Can cattle use artificial visual cues to track food locations? Abstr. 52 ${ }^{\text {nd }}$ Annual Meeting Soc. Range Manage.

Hughes, T. P., A. R. Sykes, D. P. Poppi, and J. Hodgson. 1991. The influence of sward structure on peak bite force and bite weight in sheep. Proc. New Zealand Soc. Anim. Prod. 51:153-158.

Illius, A. W. and I. J. Gordon. 1987. The allometry of food intake in grazing ruminants. J. Anim. Ecol. 56:989-999.

Illius, A. W. and I. J. Gordon. 1991 Prediction of intake and digestion in ruminants by a model of rumen kinetics integrating animal size and plant characteristics. J. Agr. Sci. 116:145-157.

Kidunda, R. S. and L. R. Rittenhouse. 1992. Temporal selection of spatially separated patches based on pairing of food and environmental cues. Proc. West. Sect. Amer. Soc. Anim. Sci. 43:408-410

Laca, E. A. 1998. Spatial memory and food searching mechanisms of cattle. J. Range Manage. 51:370-378.

Laca, E.A. and M.W. Demment. 1996 Foraging strategies of grazing animals, pp. 137-158. In: J. Hodgson and A.W. Illius (ed). The ecology and management of grazing systems. CAB Int'l. Wallingford, UK.

Laca, E. A. and I. M. Ortega. 1996. Integrating foraging mechanisms across spatial and temporal scales, pp. 129-132. In: $\mathrm{N}$ E. West (ed.), Fifth Int. Rangeland Congr. Soc. Range Manage., Salt Lake City, Utah.

Laca, E. A., E. D. Ungar, and M. W. Demment. 1994b. Mechanisms of handling time and intake rate of a large mammalian grazer. Appl. Anim. Beh. Sci. 39:3-19.

Laca, E. A., R. A. Distel, T. C. Griggs, and M. W. Demment. 1994a. Effects of canopy structure on patch depression by grazers. Ecol. 75:706-716

Laca, E. A., R. A. Distel, T. C. Griggs, G. P. Deo, and M. W. Demment. 1993. Field test of optimal foraging with cattle: the marginal value theorem successfully predicts patch selection and utilization, pp. 709-710. In: XVII International Grassland Congress, Palmerston North, Hamilton and Lincoln, New Zealand; Rockhampton, Queensland.

MacKinnon, B. W., H. S. Easton, T. N. Barry, and J. R. Sedcole. 1988. The effect of reduced leaf shear strength on the nutritive value of perennial ryegrass. J. Agr.. Sci. Cambridge III:469-474.

McLeod, M. N. and B. R. Smith. 1989. Eating and ruminating behaviour in cattle given forages differing in fibre content. Anim. Prod. 48:503-511.
McLeod, M. N., P. M. Kennedy, and D. J. Minson. 1990. Resistance of leaf and stem fractions of tropical forage to chewing and passage in cattle. Brit. J. Nutr. 63:105-119.

Milewski, A. V., T. P. Young, and D. Madden. 1991. Thorns as induced defenses: Experimental evidence. Oecologia 86:70-75.

Murray, M. G. 1991. Maximizing energy retention in grazing ruminants. J. Anim. Ecol. 60:1029-45.

Myers, J. H. and D. Bazely. 1991. Thorns, spines, prickles, and hairs: are they stimulated by herbivory and do they deter herbivores?, pp. 325-344. In: D. W. Tallamy and M. J. Rupp (eds.), Phytochemical induction by herbivores. John Wiley \& Sons, Inc., New York, N.Y.

Nelson, C.J. and L.E. Moser. 1994. Plant factors affecting forage quality, pp. 115-154. In: G. C. Fahey, Jr. (ed). Forage quality, evaluation and utilization. American Soc. Agron, Crop Sci. Soc. Amer., and Soil Sci. Soc., Madison, Wis.

Ortega, I. M. and E. A. Laca. 1997. Effects of food spatial distribution, visual and olfactory cues on feeding efficiency of cattle. Abstr. $50^{\text {th }}$ Annual meeting Soc. Range Manage.

Ortega-Reyes, L. and F. D. Provenza. 1993a. Amount of experience and age affect the development of foraging skills of goats browsing blackbrush (Coleogyne ramosissima). Appl. Anim. Behav. Sci. 36:169-83.

Ortega-Reyes, L. and F. D. Provenza. 1993b. Experience with blackbrush affects ingestion of shrub live oak by goats. J. Anim. Sci. 71:380-83.

Owen-Smith, R. N. 1988. Megaherbivores. The influence of very large body size on ecology. Cambridge Univ. Press, Cambridge, U.K.

Pellew, R. A. 1984. Food consumption and energy budgets of the giraffe. J. Appl. Ecol. 21:141-59.

Renken, W. J., L. D. Howery, G. B. Ryle, and D. W. Bailey. 1998. Location of feed rewards by beef heifers based on the presence of visual cues. Abstr. 51 ${ }^{\text {st }}$ Annual Meeting Soc. Range Manage.

Reid, E. D. 2000. Differential expression of herbivore resistance in late- and mid-seral grasses of the tall grass prairie. Ph.D. Diss, Univ. Idaho, Moscow, Ida.

Riet-Correa, F., M. C. Mendez, A. L. Schild, J. A. Oliveira and O. Zenebon. 1986. Dental lesions in cattle and sheep due to industrial pollution caused by coal combustion. Pesquisa Veterinaria Brasileira 6:23-31.

Shewmaker, G.E., H.F. Mayland, H.F. and R.C. Rosenau. 1989. Silicon in C-3 grasses: effects on forage quality and sheep preference. J. Range Manage. 42:122-127.

Shipley, L. A. and D. E. Spalinger. 1992. Mechanics of browsing in dense food patches: effects of plant and animal morphology on intake rate. Can. J. Zool. 70:1743-1752.

Shipley, L. A. and D. E. Spalinger. 1995. Influence of size and density of browse patches on intake rates and foraging decisions of young moose and white-tailed deer. Oecologia 104:112-121.
Shipley, L. A., S. Blomquist, and K. Danell. 1998. Diet choices made by free-ranging moose in northern Sweden in relation to plant distribution, chemistry, and morphology. Can. J. Zool. 76:1-12.

Shipley, L. A., J. E. Gross, D. E. Spalinger, N. T. Hobbs, and B. A. Wunder. 1994. The scaling of intake rate in mammalian herbivores. Amer. Nat. 143:1055-1082.

Shipley, L. A., A. W. Illius, K. Danell, N. T. Hobbs, and D. E. Spalinger. 1999. Predicting bite size selection of mammalian herbivores: a test of a general model of diet optimisation. Oikos 84:55-68.

Spalinger, D. E. and N. T. Hobbs. 1992. Mechanisms of foraging in mammalian herbivores: new models of functional response. Amer. Nat. 140:325-348.

Stapley, L. 1998. The interaction of thorns and symbiotic ants as an effective defense mechanism of swollen-thorn acacias. Oecologia 115:401-405.

Subbendieck, J., S. L. Hatch, and C. H. Butterfield. 1992. North American range plants. Univ. of Nebraska Press, Lincoln, Nebr.

Ungar, E. D., A. Genizi, and M. W. Demment. 1991. Bite dimensions and herbage intake by cattle grazing short hand-constructed swards. Agron. J. 83:973-978.

Van der wal, R., N. Madan, S. van Lieshout, C. Dormann, R. Langvatn, and S. P. Albon. 2000. Trading forage quality for quantity? Plant phenology and patch choice by Svalbard reindeer Oecologia 123:108-115.

Van Soest, P. J. 1982. Nutritional ecology of the ruminant. O \& B Books, Corvallis, Ore..

Van Soest, P. J. and L. H. P. Jones. 1968. Effect of silica in forages upon digestibility. J. Dairy Sci. 51:1644-1648.

Vivås, H. J. and B. Sæther. 1987. Interactions between a generalist herbivore, the moose Alces alces, and its food resources: an experimental study of winter foraging behaviour in relation to browse availability. J. Anim. Ecol. 56:509-520.

Vivås, H. J., B. E. Sæther, and R. Andersen. 1991. Optimal twig-size selection of a generalist herbivore, the moose Alces alces: Implications for the plant herbivore interactions. J. Anim. Ecol. 60:395-408. 